\title{
The Development of an Inquiry-Based Laboratory Manual for Student of Biology Education
}

\section{Azza Nuzullah Putri ${ }^{1}$}

${ }^{1}$ Maritim Raja Ali Haji University, Indonesia

A R T I C L E I N F O

Article history:

Received 10 October 2020

Received in revised

Form 06 January 2021

Accepted 20 January

February 2021

Available online 01

February 2021

Keywords:

Laboratory Manual,

Inquiry, Biology

\begin{abstract}
A B S T R A C T
Inquiry enables the student to learn through many activities that can improve student attitudes, processes, and thinking skills. Inquiry learning helps students develop their ability to solve the problem, think critically and reflectively. Applying inquiry-based activities in laboratory courses is one way to prompt the student-centered learning in general biology courses. The research aimed to develop a valid and practical inquiry-based laboratory manual for biology education students. This study used the ADDIE model to develop the product, the stages involve analysis, design, development, implementation, and evaluation. The implementation was conducted on 30 biology education students who take general biology courses. The data were collected by the validation sheet and questionnaire of student responses. The inquiry-based laboratory manual that has been developed gets a very decent category as a validation result. Practical of inquiry-based laboratory manual obtained from student response and it got a very practical category. The product is expected able to guide the student to do an inquiry process in laboratory activities.
\end{abstract}

\section{Introduction}

The challenge faced by educators at this time was associated with the advancement of technology information that impact to all aspects of life. One of them had a significant impact in the education aspect. Currently a variety of information sources are very numerous and easy to obtain. It is becoming a major challenge for educators to prepare students to learn and survive in an era where information flow runs very fast and dynamic (Nunaki, Damopolii, Kandowangko, \& Nusantari, 2019). Students are expected to have the provision of useful skills to be able to survive in the digital age. Students should be able to access, evaluate and use the information to think, learn and create. The school should give the opportunity to students to practice it at any time in every subject of the curriculum. Students should be able to understand the connection on matters that are studied with the world outside school. So the school must be able to motivate and inspire them to do their best. Various competencies required of such cooperation, the ability to think, language development, reading comprehension and social abilities (Kenengsih, 2017; Widyaningrum \& Wijayanti, 2019).

The teachers have to find the way to develop student competence for deep learning from wide range of sources of information and for finding meaning in information-laden digital environments. Many teachers are using inquiry to educate their students for an information laden society. In inquiry learning, students are trained to be able to get information at the same time develop their literacy and social skills. Inquiry is designed to enable students to gain deep personal meaning through a wide range of resources of information (Carol Collier Kuhlthau, 2008)

Providing inquiry-based activities in laboratory courses is one way to promote reformed, studentcentered teaching in introductory geoscience courses (Ryker \& McConnell, 2017). Inquiry students gained self-confidence in scientific abilities, but traditional students' gain was greater-likely indicating that the traditional curriculum promoted over-confidence. Inquiry lab students valued more authentic science exposure but acknowledged that experiencing the complexity and frustrations faced by practicing scientists was challenging, and may explain the widespread reported student resistance to inquiry curricula. Teaching inquiry-based labs involves critiquing experimental design, evaluating arguments, interpreting and solving problems, and other skills not developed in verification-style labs. These skills should be important to graduate students whose primary, if not exclusive, career goal is research (Bruck, Bretz, \& Towns, 2008). 
The scientific work skills can be trained on students, one of which is through practicum activities. Practicum is an important activity in order to support understanding of the concepts that have been previously studied in class (Damopolii, Nunaki, Nusantari, \& Kandowangko, 2020; Rahmat \& Chanunan, 2018). Based on the observations made, the practicum activities currently taking place are still using conventional practicum guides such as directions in the recipe book. So that practicum activities are focused only on following the instructions in the practicum guide without any further development of student process skills. These practical activities make students less experience in carrying out the investigation or experiment process. This of course will have an effect on student motivation to follow practicum well. This is in accordance with the results of research that has been carried out by Kenengsih (2017) after developing a microbiology practicum guide.

Several previous studies have shown that the use of a guided inquiry-based practicum guide can help increase student activity and motivation in doing practicum (Handayani, F, \& Anhar, 2014; Lubis, Silaban, \& Jahro, 2016; Nengsi, 2016; Umah, Sudarmin, \& Dewi, 2014; Waluyo \& Parmin, 2014). In addition, it also helps train students' scientific work skills (Kenengsih, 2017; Widyaningrum \& Wijayanti, 2019) and through the use of guided inquiry-based student worksheets can also improve science process skills (Saidaturrahmi, et. al. , 2019), Likewise, the use of an inquiry guide-based practicum guide can also help improve students' thinking skills (Nunaki, Damopolii, Kandowangko, \& Nusantari, 2019; Nurussaniah \& Nurhayati, 2016; Rahmat \& Chanunan, 2018).

Inquiry learning can also facilitate to develop the student's metacognitive. These research found that inquiry-based learning effectively trains students' metacognitive skill (Damopolii et al., 2020; Nunaki et. al., 2019) and open inquiry learning was more potential to facilitate high metacognitive skills in high and low academic abilities of students rather than conventional method. The interaction of the learning models and academic abilities in this study showed no significant difference of metacognitive skills (Rahmat \& Chanunan, 2018).

Based on the explanation above, it shows that the practical guide is very important to be developed to be able to equip students in practicum activities. Through a guided inquiry-based practicum guide, it is hoped that it can help students train and practice scientific work skills. Therefore, researchers also conducted research aimed at developing a guided inquiry-based manual laboratory. This guide is used by students in doing practicum in general biology courses.

\section{Methods}

The method is research and development (R\&D) which aims to produce a product and asses the product practicalities. This study developed a laboratory manual for general biology courses. Product feasibility tests conducted on 30 biology education students who take general biology subject in 2018/2019 academic year. Data collection instruments used is validation sheets for expert and questionnaire of student response. Validation products include validation on aspects of content, language and presentation that evaluated by two experts. The practicalities of test conducted on students, the aspect are: presentation, ease and suitability of time.

Laboratory manual was developed based on the learning steps in the inquiry. In this research we used instructional systems design of ADDIE model. In the ADDIE model, each step has an outcome that feeds into the subsequent step. In the analysis phase, instructional problem is clarified, the instructional goals and objectives are established and the learning environment and learner's existing knowledge and skills are identified. The design phase deals with learning objectives, assessment instruments, exercises, content, subject matter analysis, lesson planning and media selection. The design phase should be systematic and specific. The development phase is where the developers create and assemble the content assets that were created in the design phase. The project is reviewed and revised according to any feedback given During the implementation phase, a procedure for training the learners is developed. The facilitators' training should cover the course curriculum, learning outcomes, method of delivery, and testing procedures. The evaluation phase consists of two parts: formative and summative. Formative evaluation is present in each stage of the ADDIE process. Summative evaluation consists of tests designed for domain specific criterion-related referenced items and providing opportunities for feedback from the students. The phase to develop the inquiry-based laboratory manual was outlined in Table 1.

Table 1. Phases of ADDIE model

\begin{tabular}{ll}
\hline Phase & Activities \\
\hline Analysis & Analyze student's needs, analyze the curriculum and student's characteristic
\end{tabular}




\begin{tabular}{ll}
\hline Phase & Activities \\
\hline Design & $\begin{array}{l}\text { Designing concept of products, competency base and formulate the learning } \\
\text { outcome }\end{array}$ \\
Develop & $\begin{array}{l}\text { Developing the product in accordance with the learning outcome, perform a } \\
\text { validation of the product by experts }\end{array}$ \\
Implementation & $\begin{array}{l}\text { Implementing the product on students and doing product practicality test } \\
\text { Evaluation }\end{array}$ \\
\hline
\end{tabular}

\section{Result and Discussion}

\section{Results \\ Analysis Phase}

In this phase several analyzes were carried out including analysis of student needs, curriculum and student characteristics. At this stage the results of the analysis are obtained, which is related to the needs of students, namely the need for teaching materials or guidance in conducting practical activities in the laboratory that are able to facilitate the development of process skills and thinking skills of students. This shows that students need guidance that is able to direct students to carry out practical activities. Then based on the results of curriculum analysis and learning objectives obtained by several themes will be practiced. Some of the themes that are obtained include: cell structure, plant and animal tissue, biodiversity, ecology and genetics.

\section{Design Phase}

In this phase a laboratory manual design will be developed. In this phase designing concepts of products, competency base and formulate the learning outcome. This is done so that the products developed are in accordance with the learning objectives and competencies to be addressed. In this general biology course students are expected to be able to master the basic theories and concepts found in biological studies. In this activity also began the initial design of manual laboratory forms that will be developed as well as the initial preparation of focus questions that will be given to students. Focus question is useful for being able to direct students before conducting inquiry activities. The activities carried out at this stage are analyzing concepts and materials, collecting related references, formulating focus questions as an introduction to inquiry activities and designing the manual laboratory.

\section{Development Phase}

The development phase of the laboratory manual is the stage to determine the feasibility of the laboratory manual. Laboratory manual are developed in accordance with the rules for the development of predetermined teaching materials. The product developed will be validated by experts, namely two lecturers. The laboratory manual validation is conducted to find out the feasibility of the product that students will use in learning activities. Validation was carried out by two experts, namely from biology and biology education lecturers. In this validation process the expert assesses in terms of content, language and laboratory manual presentation developed. At this stage focus questions have been developed which will be the guiding questions to begin the inquiry process. This is a valid laboratory manual for use in practical activities. The results of validation can be seen in Table 2.

Table 2. Validation Result of Laboratory Manual

\begin{tabular}{lcl}
\hline Aspects & Percentages & Categories \\
\hline Content & 92 & very feasible \\
Language & 92,5 & very feasible \\
Presentation & 91,1 & very feasible \\
\hline
\end{tabular}

\section{Implementation Phase}

Products that have been validated will then be implemented through trial activities on students. The initial trial activity was carried out on a limited basis, then continued with the implementation stage. After the implementation is done, students are asked to fill out a response questionnaire. This is done to determine student responses to the application of manual laboratories that have been developed. The student responses obtained can be in the form of practical test results on the developed laboratory manual. The practical component seen includes aspects of clarity in presentation, ease and timeliness. Some of the things that are done at this stage are gathering students for trial activities, distributing practicum guides to students making observations on the use of manual laboratory. Then proceed with 
trial activities during practicum activities. The activities carried out at this stage are contacting the laboratory assistant for preparation of practicum tools and materials, guiding practicum activities, using the laboratory manual, observing the implementation of the use of the laboratory manual.

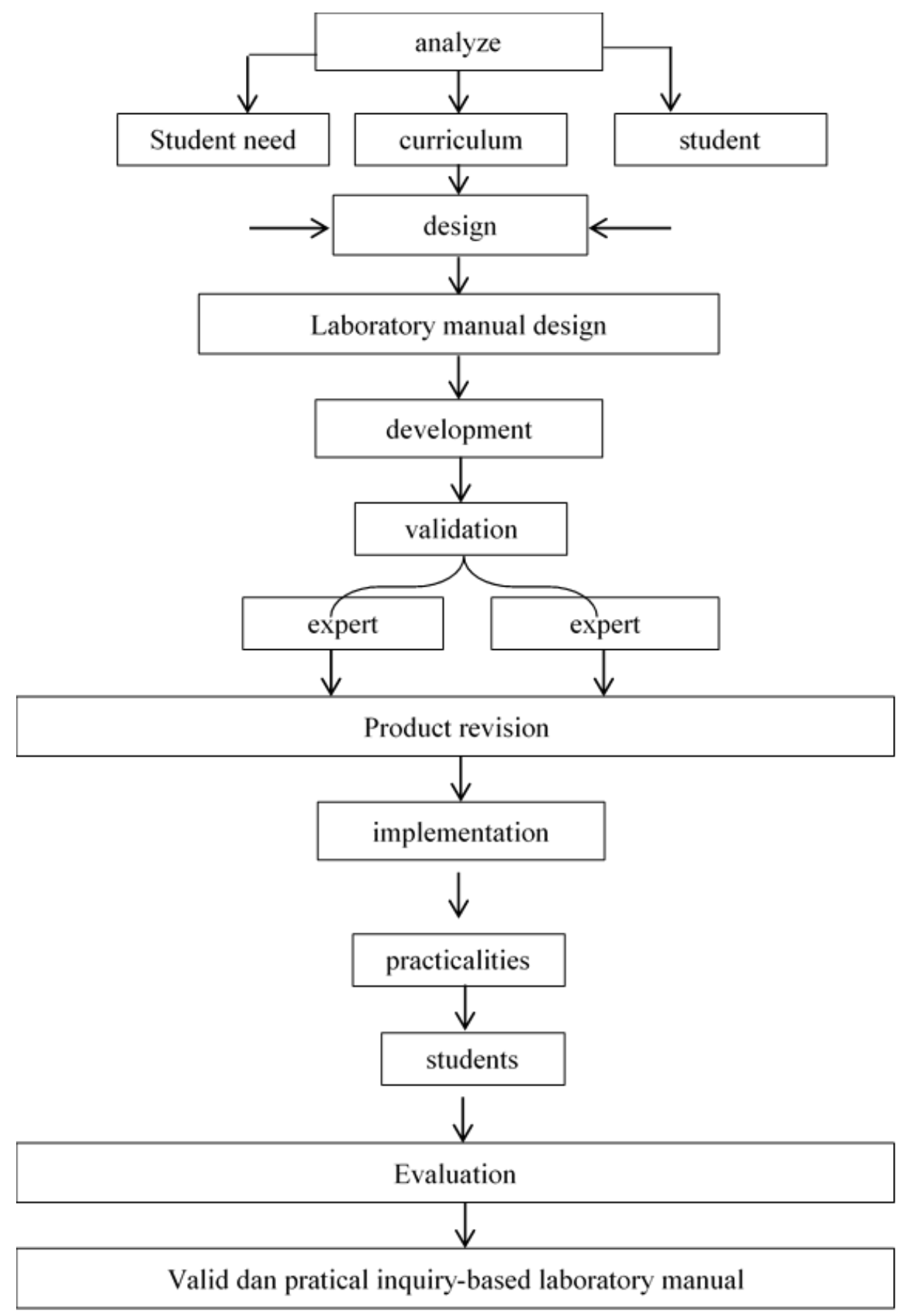

Figure 1. Research and development stages

\section{Evaluation Phase}

The evaluation phase is the final assessment given through the results data obtained from the validity and practicality of the inquiry-based manual laboratory. based on the results of product validation and the process of testing student responses, laboratory manually, the results of data analysis showed that the manual laboratory was feasible to be used. The results of student responses to the use of general biology laboratory manual can be seen in Table 3 . 
Table 3. Practicalities Result of Laboratory Manual

\begin{tabular}{lll}
\hline \multicolumn{1}{c}{ Aspects } & Percentages & Categories \\
\hline Clarity of presentation & 92,7 & very practical \\
Ease of understanding & 87,9 & very practical \\
Ease of use & 89,84 & very practical \\
Suitability of time & 78,10 & practical \\
\hline
\end{tabular}

\section{Discussion}

Guided inquiry as a learning model suitable for application in science learning. This is because this learning model is in accordance with the nature of science itself, one of which is a process. Students are required to be able to have process skills to be able to carry out an investigation or search, which later can produce science products themselves. One of these process skills is developed through practicum activities. In order for practicum activities to run well and directed, a laboratory manual is needed which can also facilitate the ability of the process.

This study produced an inquiry-based laboratory manual that was validated to be used in practical activities. Laboratory manual validation is obtained from the results of expert assessment using a validation sheet. The results of the validation of the laboratory manual developed include the three aspects, namely: content, language and presentation /graphics get a very feasible category. Inquiry is a method and stage in learning where student-centered learning and lecturers act as facilitators. Through inquiry students are required to be active in finding and finding learning concepts in order to solve problems. In the inquiry-based laboratory manual developed was equipped with a focus question as a guiding question for students in conducting practical activities. Students are asked to design their own activities to be able to find concepts from the topics being studied (French \& Russell, 2002).

The results of the content aspect validation get a very feasible category because the contents of the developed laboratory manual have met the assessment indicators. Among them is conformity with competencies and learning objectives to be achieved by students. For example, in the practicum of observing plant tissue structure, the competence that students must master is that students can distinguish the tissue structure of monocotyledon and dicotyledonous plants through observation using a microscope. Activities carried out in the practicum process have been able to support the achievement of these competencies. In the guided inquiry work step section, students are guided through the provision of focus questions that are appropriate and can guide students in finding concepts. In this laboratory manual, students are allowed to design their own practicum activities, starting with determining tools and materials to work steps. Students are allowed to determine examples of plant objects that they will observe. So that students can be actively involved in practicum activities. Besides that, this can also train students' critical thinking skills through the selection of the right tools and materials in practicum activities. By the results of research conducted by (Sulistyowati, Rohman, \& Ibrohim, 2020) states that the guided inquiry learning tool that is valid and practical can improve students' critical thinking abilities.

The results of the validation on the language aspect obtained an assessment with a very feasible category. The language used in the laboratory manual has been communicative and clear. Also, the sentences used are by the rules of Indonesian which are good and correct. The use of sentences has also been effective and efficient so that students can understand well the instructions in this laboratory manual. Besides, the use of the terms and symbols required is consistent so as not to confuse the students who use them. This can be seen in the instructions given in the laboratory manual, which are clearly presented and straightforward. In implementing inquiry activities, student communication skills can also be developed. Activities in formulating problems, determining work steps, and issuing opinions will train students' communication skills. According to research conducted by (Indriwati, Susilo, \& Anggrella, 2018) states that the inquiry learning model can improve students 'communication skills as seen from students' questioning skills orally and in writing.

In the presentation aspect, the laboratory manual developed also found a very feasible category. This can be seen from the writing in the laboratory manual that has used the right type and size of letters and is clearly legible. The selected pictures also correspond to the material discussed. For example, in the genetics practicum section, which is about variations in living things, a picture of the flower Rosa sp. which has various flower colors is presented. This shows that there are variations in the genes of flower color in Rosa sp. and are by the practicum that will be carried out. Then the colors used are also attractive so that readers become interested in using them. The results of this validation are by the student's response to the clarity aspect of the presentation from the laboratory manual. The results obtained in this aspect belong to the very practical category. This aspect received the highest rating compared to other practical 
aspects. This shows that students can use laboratory manuals in practicum activities well. Presentation of images, instructions, and writing in the laboratory manual can be clearly read by students so that they can support the implementation of practicum

Based on the results of student responses to laboratory manual that have been developed, it was found that in each aspect a positive response was received. This is in line with the results of research conducted by (Nengsi, 2016) which states that the use of guided inquiry-based practicum guides can make students more active. Guided inquiry-based laboratory manual can also help train science process skills through inquiry activities (Lubis et al., 2016). The clarity aspect of presentation, ease of understanding and use gets a very practical category. While in the time suitability category get a practical category. In terms of the suitability of time provided, some students experience a lack of time. This is because during the laboratory activities there were technical problems. Like during the use of a microscope, so that the time to do observation was very short. It is expected that before laboratory activities can be carried out checking the device again so that there is no interference when the laboratory takes place. Therefore, in making laboratory manuals, more attention must be paid to the allocation of time so that practicum activities can run well. This is by (Astuti \& Setiawan, 2013) suggestion by research related to the development of student's worksheets based on guided inquiry.

The aspect of ease of understanding and use also gets a very practical category. Students consider that the laboratory manual developed can help them understand the practicum activities to be carried out. The focus questions gave help them understand and find related concepts. Students feel very happy to be involved in all stages of practicum activities. Starting from determining the tools and materials then the work steps to be carried out until concluding.

Through this guiding development, it is expected that optimization in general biology laboratory activities in Biology Education study programs can be achieved. This will have an impact on improving process skills and thinking skills of students so that they can produce quality graduates. This is in line with the results of research conducted by (Syamsu, 2017) which states that inquiry-based manual laboratory can provide direct experience to students because students are directly involved in it. Inquiry-based manual laboratory. Classroom action research conducted by (Widyaningrum \& Wijayanti, 2019) also shows that the use of guided inquiry-based biochemistry practicum books is effective in improving students' scientific work ability. In addition, the use of practicum guides can also increase student motivation in carrying out these practicum activities according to the results of research that has been conducted by (Kenengsih, 2017).

\section{Conclusion}

The development of a guided inquiry-based practicum guide can be done well. Development is carried out using the ADDIE model including the stages of analysis, design, development, implementation and evaluation. Based on the results of the research and discussion on the development of laboratory manual, it can be concluded that the laboratory manual developed based on expert validation belongs to the very feasible category and in laboratory manual practice, it is found that the categories are very practical in the aspects of presentation and convenience. Whereas in the aspect of use time gets a practical category. Laboratory manuals that have been developed are expected to facilitate the development of students 'process skills in laboratory activity and also help to develop the biology students' thinking skills.

\section{References}

Astuti, Y., \& Setiawan, B. (2013). Pengembangan lembar kerja siswa (LKS) berbasis pendeka-tan inkuiri terbimbing dalam pembelajaran kooperatif pada materi kalor. Jurnal Pendidikan IPA Indonesia, 2(1), 88-92. https://doi.org/10.15294/jpii.v2i1.2515.

Bruck, L. B., Bretz, S. L., \& Towns, M. H. (2008). Characterizing the Level of Inquiry in the Undergraduate Laboratory. Journal of College Science Teaching, 38(1), 52-58. https://cursa.ihmc.us/rid=1Q3XD4DZ3-1WDCR3Y-.

Carol Collier Kuhlthau. (2008). Guided Inquiry: Learning in the 21st Century (review). Portal: Libraries and the Academy, 8(3), 339-340. https://doi.org/10.1353/pla.0.0010.

Damopolii, I., Nunaki, J. H., Nusantari, E., \& Kandowangko, N. Y. (2020). The effectiveness of Inquiry-based learning to train students' thinking skill based on SOLO taxonomy. Journal of Physics: Conference Series, 1567(4), 505-516. https://doi.org/10.1088/1742-6596/1567/4/042025. 
French, D., \& Russell, C. (2002). Do graduate teaching assistants benefit from teaching inquiry-based laboratories? BioScience, 52(11), 1036-1041. https://doi.org/10.1641/00063568(2002)052[1036:DGTABF]2.0.C0;2.

Gormally, C., Brickman, P., Hallar, B., \& Armstrong, N. (2009). Effects of Inquiry-based Learning on Students' Science Literacy Skills and Confidence. International Journal for the Scholarship of Teaching and Learning, 3(2). https://doi.org/10.20429/ijsotl.2009.030216.

Handayani, L. P., F, F., \& Anhar, A. (2014). Pengembangan Buku Penuntun Praktikum IPA Berbasis Inkuiri Terbimbing Untuk SMP Kelas VII Semester II. 69-76. https://ejournal.unp.ac.id/index.php/kolaboratif/article/view/4939.

Indriwati, S. E., Susilo, H., \& Anggrella, D. P. (2018). Penerapan Model Pembelajaran Inkuiri Terbimbing Berbasis Lesson Study pada Matakuliah Keanekaragaman Hewan untuk Meningkatkan Kecakapan Komunikasi dan Hasil Belajar Kognitif Mahasiswa Pendidikan Biologi. Jurnal Pendidikan Biologi, 9(2), 38-46. http://dx.doi.org/10.17977/um052v9i2p38-46.

Kenengsih, S. (2017). Pengembangan Penuntun Praktikum Mikrobiologi Berorientasi Inkuiri Terbimbing Untuk Mahasiswa Stkip Pgri Sumatera Barat. Saintifik, 1(2). http://dx.doi.org/10.33387/sjk.v1i2.534.

Lubis, L. T., Silaban, R., \& Jahro, S. (2016). Pengembangan Penuntun Praktikum Kimia Dasar I Terintegrasi $\begin{array}{llll}\text { Pendekatan Inkuiri. Jurnal Pendidikan } & \text { Kimia, }\end{array}$ https://doi.org/10.24114/jpkim.v8i2.4435.

Nengsi, sri. (2016). Pengembangan Penuntun Praktikum Biologi Umum Berbasis Inkuiri Terbimbing Mahasiswa Biologi STKIP Payakumbuh. Jurnal Ipteks Terapan, 10(1), 1-10. https://doi.org/10.22216/jit.2016.10.1.343.

Nunaki, J. H., Damopolii, I., Kandowangko, N. Y., \& Nusantari, E. (2019). The effectiveness of inquiry-based learning to train the students' metacognitive skills based on gender differences. International Journal of Instruction, 12(2), 505-516. https://doi.org/10.29333/iji.2019.12232a.

Nurussaniah, N., \& Nurhayati, N. (2016). Berbasis Guided Inquiry Untuk Meningkatkan Kemampuan. Prosiding Seminar Nasional Fisika, V, 63-68. https://doi.org/10.21009/0305010214.

Rahmat, I., \& Chanunan, S. (2018). Open inquiry in facilitating metacognitive skills on high school biology learning: An inquiry on low and high academic ability. International Journal of Instruction, 11(4), 593-606. https://doi.org/10.12973/iji.2018.11437a.

Ryker, K. D., \& McConnell, D. A. (2017). Assessing Inquiry in Physical Geology Laboratory Manuals. Journal of Geoscience Education, 65(1), 35-47. https://doi.org/10.5408/14-036.1.

Sulistyowati, E., Rohman, F., \& Ibrohim. (2020). Perangkat Pembelajaran Inkuiri Terbimbing Berbantuan Handout Berbasis Potensi Lokal Hutan Mangrove untuk Meningkatkan Kemampuan Berpikir Kritis dan Sikap Peduli Lingkungan. Jurnal Pendidikan, 5(3), 374-379. http://dx.doi.org/10.17977/jptpp.v5i3.13272.

Syamsu, F. D. (2017). Pengembangan Penuntun Praktikum Ipa Berbasis Inkuiri Terbimbing Untuk Siswa SMP Siswa Kelas VII Semester Genap. BIOnatural, 4(2), 13-27. https://ejournal.stkipbbm.ac.id/index.php/bio/article/view/190.

Umah, S. K., Sudarmin, S., \& Dewi, N. R. (2014). Pengembangan Petunjuk Praktikum IPA Terpadu Berbasis Inkuiri Terbimbing pada Tema Makanan dan Kesehatan. Unnes Science Education Journal, 3(2). 511-518. https://journal.unnes.ac.id/sju/index.php/usej/article/view/4267.

Waluyo, M. E., \& Parmin. (2014). Pengembangan Panduan Praktikum Ipa Terpadu Berbasis Inkuiri Terbimbing Tema Fotosintesis Untuk Menumbuhkan Keterampilan Kerja Ilmiah Siswa Smp. USEJ - Unnes Science Education Journal, 3(3). https://doi.org/10.15294/usej.v3i3.4286.

Widyaningrum, D. A., \& Wijayanti, T. (2019). Implementasi buku petunjuk praktikum biokimia berbasis inkuiri terbimbing untuk meningkatkan kemampuan kerja ilmiah. Edubiotik: Jurnal Pendidikan, Biologi Dan Terapan, 4(02), 58-67. https://doi.org/10.33503/ebio.v4i02.437. 